\title{
SISTEM INFORMASI LAYANAN PEMINJAMAN FASILITAS IT (IT HELP-DESK MANAGEMENT SYSTEM)
}

\author{
Frasiska Wiranti' , Yudhi Kurniawan ${ }^{2)}$ \\ 1,2) Sistem Informasi Universitas Machung, Villa Puncak Tidar Blok N-1 Malang, Indonesia \\ email :321410003@student.machung.ac.id ${ }^{l)}$,yudhi.kurniawan@machung.ac.id ${ }^{2}$
}

\begin{abstract}
Abstrak
Universitas Ma Chung merupakan salah satu perguruan tinggi swasta di Kota Malang. Dalam rangka memenuhi kebutuhan seluruh sivitas akademik, Universitas Ma Chung menyediakan beberapa fasilitas mulai dari barang IT, layanan perbaikan fasilitas IT dan layanan mahasiswa. Hingga saat ini, Universitas Ma Chung masih menggunakan cara manual dengan menggunakan Ms, Excel untuk mencatat permohonan peminjaman barang IT, perbaikan dan permohonan layanan. Selain itu, pengguna yang akan melakukan peminjaman juga harus membuat surat pinjaman dan kemudian diberikan kepada kepala divisi. Pengguna juga tidak dapat mengetahui apakah barang yang akan dipinjam masih ada pada tanggal yang diajukan atau tidak. Jika tidak, maka calon pengguna harus membuat ulang surat peminjaman fasilitas. Berdasarkan latar belakang, terdapat tiga masalah utama dalam proses layanan. Pertama, permohonan peminjaman fasilitas IT, permohonan perbaikan dan permohonan layanan IS/IT serta penjadwalan masih dilakukan dengan cara manual. Kedua, keluar masuk fasilitas Universitas yang dipinjam tidak dapat dipantau secara realtime. Ketiga, tidak adanya grafik laporan yang menunjukkan berapa banyak fasilitas Universitas yang dipinjam. Pengembangan sistem dilakukan dengan metode Three Major Phase yang dibagi dalam tiga fase utama, yaitu analisis, desain, dan implementasi. Sistem ini diharapkan dapat membantu Universitas Ma Chung untuk memantau perkembangan alur bisnis peminjaman, perbaikan dan layanan IS/IT. Hasil akhir yang didapat adalah laporan keluar masuk barang universitas serta jadwal peminjaman, perbaikan dan layanan.
\end{abstract}

\section{Kata kunci :}

Penjadwalan, peminjaman, perbaikan, layanan IT, help-desk.

\begin{abstract}
Universitas Ma Chung is one of Malang's independent universities. In order to fulfill needs for all academic community, Universitas Ma Chung has some facilities, i.e. IT good, IT facility repair services, and student service. Universitas Ma Chung is still using Microsoft Excel to record applications for borrowing, repairing and requesting IT goods. Nevertheless, the user who borrows the good must apply a loan letter to the Head of Division. The user is also not sure if the good is available or not for that date. Otherwise, the loan latter must be re-applied by the user. Based on this study, Universitas Ma Chung has three major service problems. First, IT borrowing applications, IS/IT loan and service applications, and manual scheduling applications. Second, the inability to detect loans for IT goods in the exact time. Thirdly, no data graph shows how many IT goods have been borrowed. System development conducts three major phase methods. It is divided into three main phases, i.e. Analysis, Design, and Implementation. It will hopefully assist Universitas Ma Chung in monitoring the loan system, improvement and IS/IT service. The final result of this study is a loan report and its loan schedule, improvement, and service.
\end{abstract}

Keywords :

Scheduling, loaning, improvement, IT service, help-desk.

\section{PENDAHULUAN}

Universitas Ma Chung merupakan salah satu perguruan tinggi swasta di Kota Malang. Dalam rangka memenuhi kebutuhan seluruh sivitas akademik, Universitas Ma Chung menyediakan beberapa fasilitas mulai dari barang IT, layanan perbaikan fasilitas IT Universitas Ma Chung dan layanan mahasiswa. Fasilitas yang disediakan tersebut dapat digunakan oleh seluruh sivitas akademik dengan cara mengajukan surat kepada kepala departemen sesuai dengan kebutuhan atau fasilitas yang akan dipinjam dan juga layanan yang diperlukan, seperti lupa password OWA atau MaCis. 
Hingga saat ini, Universitas Ma Chung masih menggunakan cara manual dengan menggunakan cara manual yaitu dengan menggunakan buku besar untuk mencatat permohonan peminjaman barang IT, perbaikan fasilitas IT dan permohonan layanan. Belum ada laporan rinci yang dapat memudahkan masing-masing kepala divisi untuk mengetahui berapa banyak barang yang masih dipinjam dan berapa banyak yang belum kembali. Selain itu, kepala divisi juga tidak dapat melihat berapa banyak fasilitas yang harus diperbaiki dan berapa banyak permohonan layanan yang telah diselesaikan dalam satu bulan.

Selain itu, pengguna yang akan melakukan peminjaman juga harus membuat surat pinjaman dan kemudian diberikan kepada kepala divisi. Pengguna juga tidak dapat mengetahui apakah barang yang akan dipinjam masih ada pada tanggal yang diajukan atau tidak. Jika tidak, maka calon pengguna harus membuat ulang surat peminjaman fasilitas. Kegiatan ini membutuhkan banyak waktu dan kurang efisien. Oleh karena itu Universitas Ma Chung membutuhkan sebuah sistem informasi penjadwalan peminjaman fasilitas IT, permohonan perbaikan perangkat IT universitas dan layanan SI/IT.

Penggunaan sistem baru juga memungkinkan pengguna maupun kepala divisi lebih menghemat waktu. Siklus yang dikerjakan mencakup peminjaman fasilitas Universitas barang IT, permohonan perbaikan fasilitas IT universitas dan permohonan layanan. Pengembangan sistem dilakukan dengan metode Three Major Phase yang dibagi dalam tiga fase utama, yaitu analisis, desain, dan implementasi. Sistem ini diharapkan dapat membantu Universitas Ma Chung untuk memantau perkembangan alur bisnis peminjaman, perbaikan dan layanan IS/IT Adapun batasan masalah dalam penelitian ini adalah Sistem dikembangkan pada siklus permohonan peminjaman fasilitas IT Universitas Ma Chung. Sistem dikembangkan pada siklus permohonan perbaikan fasilitas Universitas Ma Chung seperti LCD, AC dan lain-lain. Sistem dikembangkan pada siklus permohonan layanan IS/IT, seperti permohonan perbaikan password MaCis. Sistem dikembangkan pada siklus penjadwalan peminjaman fasilitas IT Universitas Ma Chung dan penjadwalan perbaikan fasilitas IT Universitas Ma Chung. Sistem hanya dapat digunakan oleh seluruh sivitas akademi Universitas Ma Chung, yaitu mahasiswa, dosen dan staff Universitas Ma Chung. Output yang merupakan laporan keluar masuk fasilitas IT, laporan perbaikan fasilitas IT, laporan layanan IS/IT dan juga grafik laporan bulanan peminjaman, perbaikan dan layanan IS/IT pada Universitas Ma Chung.

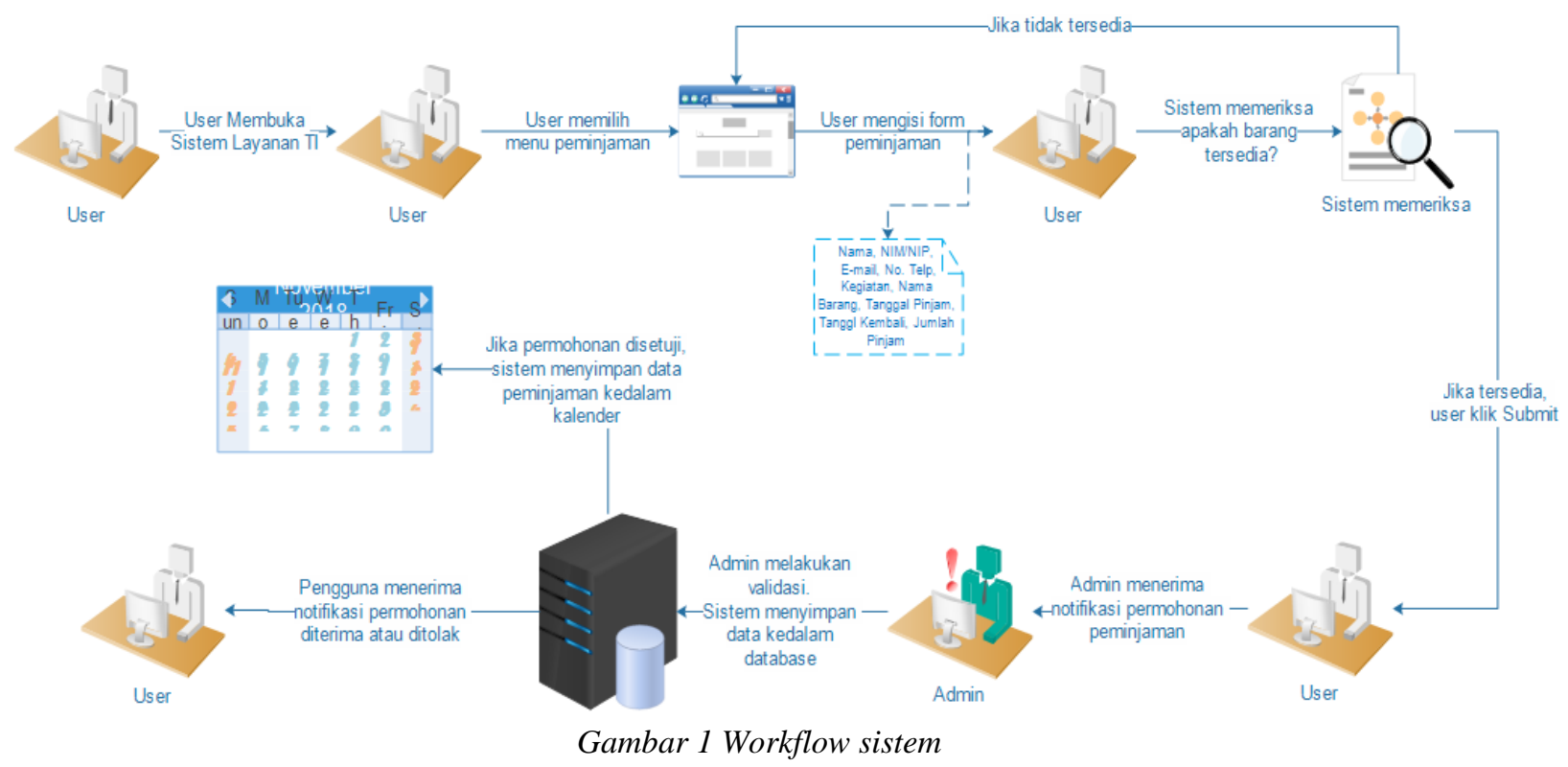




\subsection{Tinjauan Pustaka}

Penelitian terdahulu yang berjudul "Sistem Informasi E-event (studi kasus: Universitas Ma Chung)". Pada aplikasi ini, laporan yang dihasilkan adalah laporan peminjaman fasilitas, laporan pengembalian fasilitas dan laporan kondisi fasilitas. Aplikasi ini dibuat dengan menggunakan bahasa pemrograman PHP dan database oracle. Metode pengembangan sistem menggunakan metode waterfall sedangkan untuk metode perancangan sistem menggunakan System Development Life Cycle (SDLC) [1].

Penelitian lain yang diambil berjudul "Sistem Informasi Jasa Service Software Hardware pada CV. Duta Teknologi Berbasis Dekstop”. Penelitian ini dibuat karena pengelolaan data-data masih dilakukan secara manual dengan support microsoft office yang pengolahan datanya cukup sederhana dan perlu diperbaiki hal ini ditunjukan dengan lambatnya pencarian data yang di perlukan sehingga dapat berimbas pada proses pembuatan laporan. Hal ini mempengaruhi kinerja dari penyediaan informasi yang baik. Selain itu data yang masuk terusmenerus berubah, sehingga informasi yang di hasilkan akan selalu berkembang. Aplikasi ini dibuat dengan menggunakan bahasa pemrograman Java dan database MySQL. Metode pengembangan yang digunakan adalah prototype model [2].

Penelitian lainnya yang berjudul "Analisis dan Perancangan Sistem Informas IT-Helpdesk pada PT. Lontar Papyrus Pulp \& Paper Industry”. Penelitian ini dibuat berdasarkan beberapa masalah yang diterima oleh bagian Department Information Technology sering mengalami kesulitan dalam menentukan dan mengatasi skala pengerjaanya (emergency, urgent, dan normal) dikarenakan tidak adanya sistem

penentuan skala prioritas dan manajemen layanan service user terpusat. Untuk mengatasi masalah tersebut dibutuhkan suatu Sistem Informasi IT Help-desk untuk memanajemen semua permintaan service dari user. Hasil dari penelitian berupa prototype Sistem Informasi IT-Helpdesk berbasis web yang menyediakan layanan dan informasi yang dibutuhkan serta dapat membantu semua user yang ada di perusahaan tersebut umumnya dan khususnya[3].

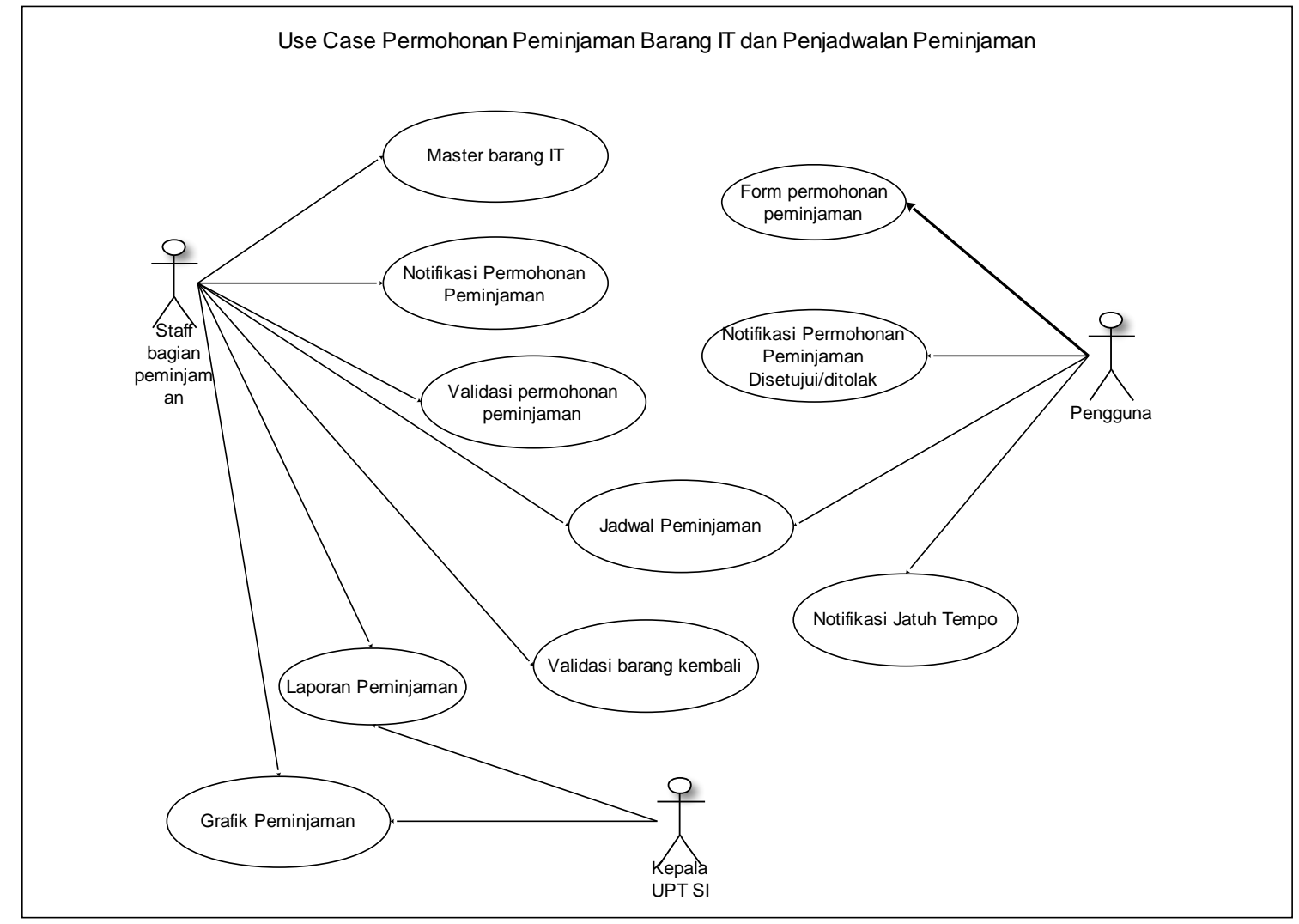

Gambar 2 Use case peminjaman fasilitas IT 
Berbeda dengan sistem ini yang akan dikembangkan pada seluruh fasilitas IT di Universitas Ma Chung yang membutuhkan perbaikan. Selain itu sistem yang akan dikembangkan juga menyediakan fitur permohonan peminjaman barang IT, penjadawalan peminjaman barang dan permohonan layanan IS/IT. Laporan yang dibuat juga lebih lengkap karena terdapat laporan banyaknya perbaikan yang dilakukan serta banyaknya permohonan yang telah terselesaikan dalam kurun waktu tertentu. Sistem dikembangkan dengan metode Three Major Phase, bahasa pemrograman PHP, dan database MySQL.

Three Major Phases merupakan bagian dari SDLC yaitu 3 tahapan utama yang terdapat pada setiap metodologi. Bertujuan untuk menganalisis penelitian atau proyek kemudian mendesain sistem yang merupakan proyek tersebut, yakni solusi dari analisis yang telah dilakukan, kemudian membangun dan menerapkan sistem tersebut [4].

Sistem informasi informasi layanan TI Universitas Ma Chung (IT help-deskk management system) utama, yaitu:

1) Peminjaman fasilitas IT Universitas

2) Permohonan perbaikan fasilitas Universitas

3) Permohonan layanan data

Gambar 2 menggambarkan use case untuk peminjaman barang dan penjadwalan. Aktor yang terlibat kepala UPT SI, Staff bagian peminjaman dan penjadwalan serta pengguna. Staff bagian peminjaman dan penjadwalan dapat mengakses semua master dan transaksi, kepala UPT SI dapat melihat laporan peminjaman dan grafik peminjaman, sedangkan pengguna hanya bisa mengisi form permohonan peminjaman, menerima notifikasi peminjaman disetujui, melihat jadwal peminjaman dan menerima notifikasi peminjaman jatuh tempo.

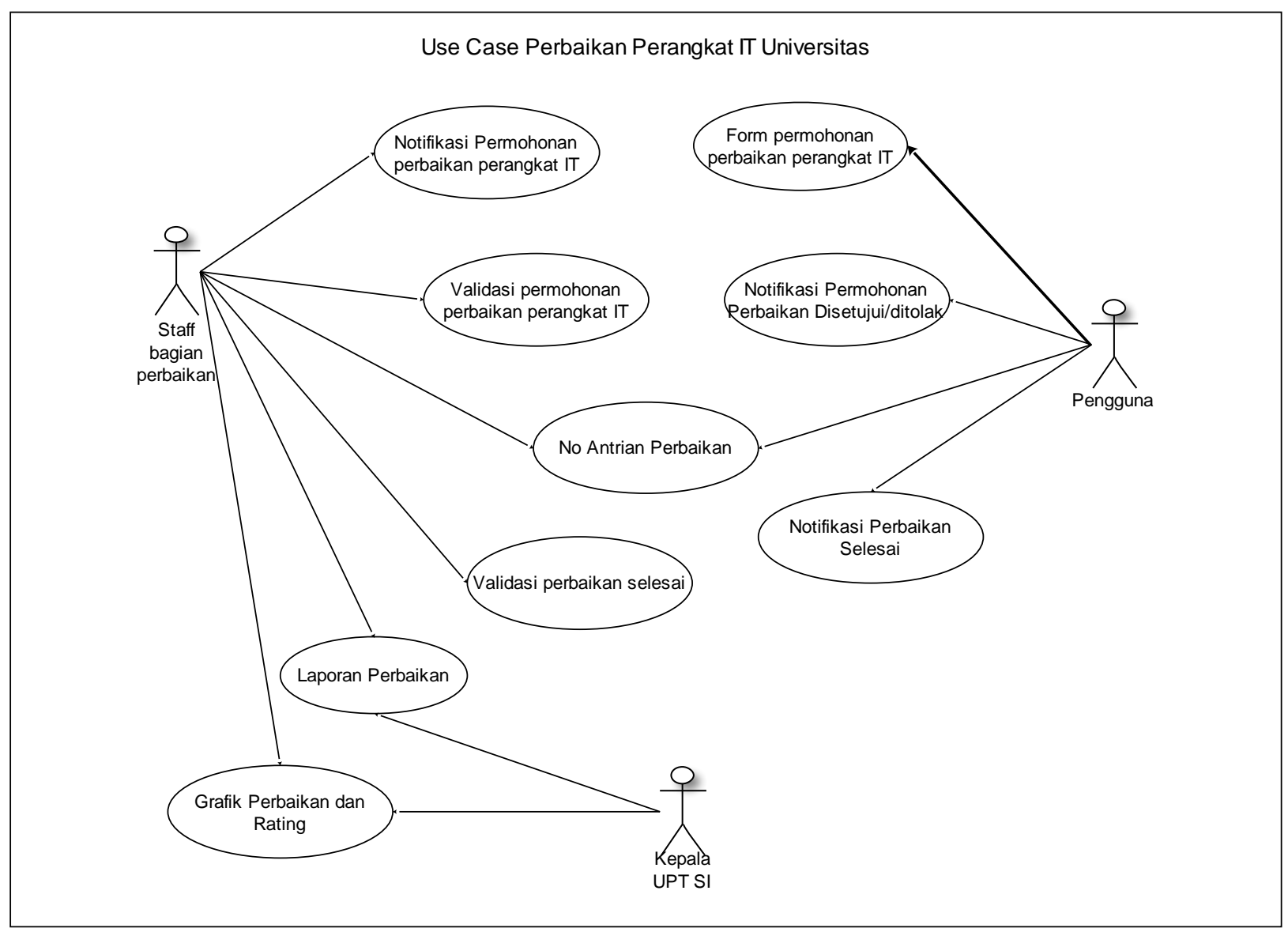

Gambar 3 Use case perbaikan fasilitas IT 
Gambar 3 menggambarkan use case untuk proses perbaikan perangkat IT Universitas. Aktor yang terlibat kepala UPT SI, Staff bagian perbaikan serta pengguna. Staff bagian perbaikan dapat mengakses transaksi, kepala UPT SI dapat melihat laporan perbaikan dan grafik serta perbaikan, sedangkan pengguna hanya bisa mengisi form permohonan perbaikan, menerima notifikasi perbaikan disetujui, menerima nomor antrian perbaikan, menerima notifikasi perbaikan selesai dikerjakan.

Gambar 4 menggambarkan use case untuk layanan IS/IT. Aktor yang terlibat kepala UPT SI, Staff bagian layanan IS/IT serta pengguna. Staff bagian IS/IT dapat mengakses transaksi, kepala UPT SI dapat melihat laporan layanan IS/IT dan grafik layanan, sedangkan pengguna hanya bisa mengisi form permohonan layanan, menerima notifikasi layanan disetujui, menerima notifikasi layanan selesai dikerjakan.

Basis data adalah media untuk menyimpan data agar dapat diakses dengan mudah dan cepat [5].

PHP berasal dari kata "Hypertext Preprocessor", yaitu bahasa pemrograman universal untuk penanganan pembuatan dan pengembangan sebuah situs web dan bisa digunakan bersamaan HTML. Saat ini, PHP banyak dipakai untuk membuat program situs web dinamis [6].

MySQL adalah sistem manajemen database SQL yang sifatnya open source (terbuka) dan paling banyak digunakan saat ini. Sistem database MySQL mampu mendukung beberapa fitur seperti multithreaded, multi-user, dan SQL database management system (DBMS) [7].

Use case atau diagram use case merupakan permodelan untuk kelakuan (behavior) sistem informasi yang akan dibuat [8].

Diagram aktivitas atau activity diagram menggambarkan workflow (aliran kerja) atau aktivitas dari sebuah sistem atau proses bisnis atau menu yang ada pada perangkat lunak [8].

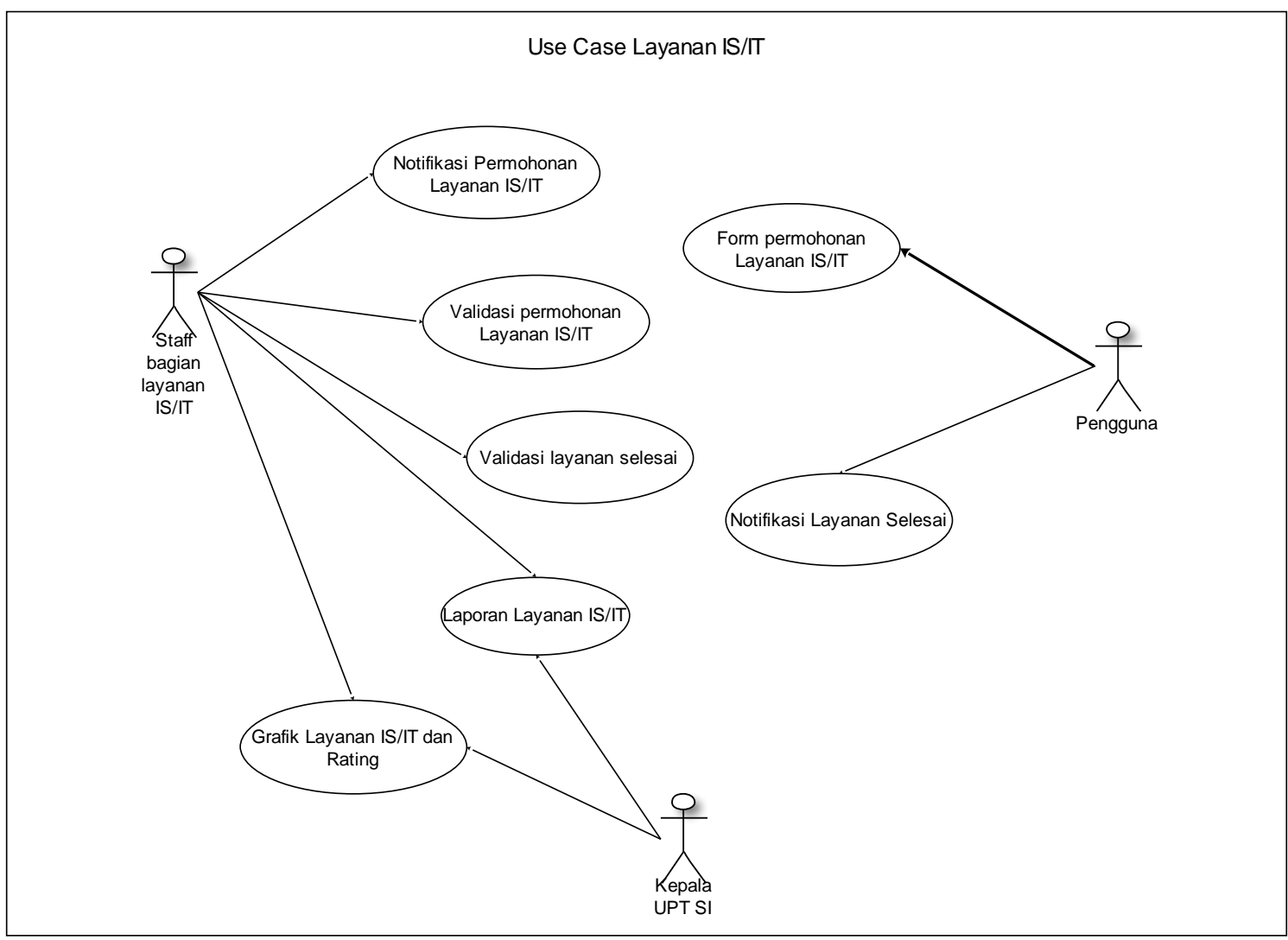

Gambar 4 Use case layanan IT 


\section{METODE / ALGORITMA}

Metode pengembangan sistem menggunakan Three Major Phases dengan tiga langkah utama yaitu analisis, desain, dan implementasi. Pada jurnal ini hanya dibahas dua langkah utama saja yaitu tahap analisis dan desain sistem.

1) Analisis, yang terdiri dari:

a. Pengumpulan data (data gathering).

Tahap ini dilakukan dengan mewawancarai kepala UPT sistem informasi Universitas Ma Chung yaitu bapak Yudhi Kurniawan.

b. Analisis keputusan dan arus data (data flow and decision analysis)

Berdasarkan hasil analisis yang telah dilakukan terdapat beberapa kebutuhan informasi pengguna yang akan terdapat didalam sistem informasi layanan TI Universitas Ma Chung.

Selain itu, pada tahap ini juga dirancang kebutuhan fungsional sistem antara lain sebagai berikut:

- Sistem dapat merekap dan menghitung total permohonan, baik permohonan peminjaman barang, permohonan perbaikan dan permohonan layanan IS/IT.

- Sistem dapat membuat penjadwalan secara otomatis berdasarkan validasi dari staff.

- Sistem dapat mengirimkan notifikasi pada staff dan calon pengguna.

- Sistem dapat mencatat, mengolah, dan menampilkan laporan berupa grafik.

Tahap ini juga membahas kebutuhan informasi pengguna (Tabel 1).

2) Desain, yang terdiri dari:

a. Data organization berupa perancangan Entity Relational Diagram (ERD), yaitu ERD sistem informasi manajemen layanan TI Universitas Ma Chung (IT Helpdesk management system) (Gambar 5).

b. Desain data entri (data entry design). Tahap ini mencakup perancangan use case dan diagram aktivitas. Diagram aktivitas yang digunakan dalam perancangan sistem.

3) Implementasi, yang terdiri dari:

a. Permohonan peminjaman fasilitas IT,

b. Permohonan perbaikan fasilitas, dan

c. Permohonan layanan data.

Form peminjaman fasilitas IT Universitas Ma Chung dalam sistem ini adalah sebagai berikut:

- Form permohonan peminjaman (Gambar 6).

Sistem menampilkan form input data peminjam, kemudian pengguna menginputkan data diri dengan NIM atau NIP, alamat e-mail yang terdaftar di Universitas Ma Chung, kemudian pengguna mengklik tombol submit untuk menyimpan data. Kemudian sistem akan menampilkan form peminjaman barang. Pengguna mengisi form peminjaman barang dnegan memilih barang yang akan dipinjam, tanggal pinjam dan tanggal kembali, kemudian pengguna mengklik tombol cari untuk memeriksa ketersediaan barang. Jika barang tersedia, maka sistem akan menampilkan tabel daftar barang berdasarkan kategori yang dipilih. Pengguna dapat langsung mengklik tombol pilih untuk menyimpan barang yang dipilih.

- Form permohonan perbaikan fasilitas Universitas (Gambar 7).

Sistem menampilkan form permohonan perbaikan fasilitas, kemudian pengguna menginputkan data diri berserta foto barang yang rusak, ruangan dan keterangan kerusakan barang. Kemudian pengguna mengklik tombol simpan untuk menyimpan permohonan perbaikan. 
Tabel 1 Kebutuhan Informasi Pengguna

\begin{tabular}{|c|c|c|c|}
\hline No & Pengguna & Hak Akses & Kebutuhan \\
\hline \multirow[t]{4}{*}{1.} & \multirow[t]{4}{*}{$\begin{array}{l}\text { Staff Peminjaman } \\
\text { dan Penjadwalan }\end{array}$} & $\begin{array}{ll}\text { 1. } & \text { Menerima notifikasi permohonan peminjaman } \\
\text { 2. } & \text { Melakukan validasi permohonan peminjaman } \\
\text { 3. } & \text { Melihat jadwal peminjaman } \\
\end{array}$ & $\begin{array}{l}\text { Data transaksi } \\
\text { peminjaman barang IT } \\
\text { dan penjadwalan. }\end{array}$ \\
\hline & & $\begin{array}{ll}\text { 4. } & \text { Mengirimkan notifikasi barang jatuh tempo } \\
\text { 5. } & \text { Memvalidasi barang kembali } \\
\text { 6. } & \text { Melihat stok barang terupdate }\end{array}$ & $\begin{array}{l}\text { Data peminjaman } \\
\text { barang (nama } \\
\text { peminjam, alamat } e \text { - } \\
\text { mail, no telepon, } \\
\text { barang dipinjam, } \\
\text { tanggal kembali) }\end{array}$ \\
\hline & & $\begin{array}{ll}\text { 7. } & \text { Melihat rekap transaksi peminjaman } \\
\text { 8. } & \text { Melihat grafik peminjaman barang }\end{array}$ & Semua data transaksi \\
\hline & & $\begin{array}{ll}\text { 9. } & \text { Mencatat data master barang } \\
\text { 10. } & \text { Mencatat data master ruangan }\end{array}$ & $\begin{array}{l}\text { Semua data ruangan } \\
\text { serta barang IT dan } \\
\text { yang dapat dipinjam. }\end{array}$ \\
\hline \multirow[t]{3}{*}{2.} & \multirow[t]{3}{*}{$\begin{array}{l}\text { Staff Perbaikan } \\
\text { perangkat IT } \\
\text { Universitas }\end{array}$} & $\begin{array}{l}\text { 1. Menerima notifikasi permohonan perbaikan } \\
\text { perangkat IT } \\
\text { 2. Melakukan validasi permohonan perbaikan }\end{array}$ & $\begin{array}{l}\text { Data transaksi } \\
\text { permohonan perbaikan } \\
\text { perangkat IT } \\
\text { Universitas }\end{array}$ \\
\hline & & $\begin{array}{l}\text { 3. } \begin{array}{l}\text { Mengirimkan notifikasi perbaikan sudah selesai } \\
\text { dikerjakan }\end{array}\end{array}$ & $\begin{array}{l}\text { Data perbaikan } \\
\text { perangkat IT } \\
\text { Universitas }\end{array}$ \\
\hline & & $\begin{array}{l}\text { 4. } \text { Melihat rekap transaksi perbaikan } \\
\text { 5. } \text { Melihat grafik perbaikan }\end{array}$ & $\begin{array}{l}\text { Semua data transaksi } \\
\text { perbaikan perangkat IT } \\
\text { Universitas }\end{array}$ \\
\hline \multirow[t]{3}{*}{3.} & \multirow[t]{3}{*}{$\begin{array}{l}\text { Staff Perbaikan } \\
\text { perangkat IT } \\
\text { Universitas }\end{array}$} & $\begin{array}{l}\text { 1. } \text { Menerima notifikasi permohonan layanan IS/IT } \\
\text { 2. } \text { Melakukan validasi permohonan perbaikan }\end{array}$ & $\begin{array}{l}\text { Data transaksi } \\
\text { permohonan layanan } \\
\text { IS/IT }\end{array}$ \\
\hline & & $\begin{array}{ll}\text { 3. } & \text { Mengirimkan notifikasi layanan IS/IT sudah } \\
\text { selesai dikerjakan }\end{array}$ & Data layanan IS/IT \\
\hline & & $\begin{array}{ll}\text { 4. } & \text { Melihat rekap transaksi layanan IS/IT } \\
\text { 5. } & \text { Melihat grafik layanan IS/IT }\end{array}$ & $\begin{array}{l}\text { Semua data transaksi } \\
\text { layanan IS/IT }\end{array}$ \\
\hline \multirow[t]{4}{*}{4.} & \multirow[t]{4}{*}{ Kapala UPT SI } & 6. Mencatat data master user & $\begin{array}{l}\text { Data } \text { user yang dapat } \\
\text { masuk kedalam sistem. }\end{array}$ \\
\hline & & $\begin{array}{ll}\text { 7. } & \text { Melihat rekap transaksi perbaikan } \\
\text { 8. } & \text { Melihat grafik perbaikan } \\
\end{array}$ & $\begin{array}{l}\text { Data rekap transaksi } \\
\text { perbaikan }\end{array}$ \\
\hline & & $\begin{array}{ll}\text { 9. } & \text { Melihat rekap transaksi peminjaman } \\
\text { 10. } & \text { Melihat grafik peminjaman barang }\end{array}$ & $\begin{array}{l}\text { Data rekap transaksi } \\
\text { peminjaman dan } \\
\text { penjadwalan }\end{array}$ \\
\hline & & $\begin{array}{l}\text { 11. Melihat rekap transaksi layanan IS/IT } \\
\text { 12. Melihat grafik layanan IS/IT }\end{array}$ & $\begin{array}{l}\text { Data rekap transaksi } \\
\text { layanan IS/IT }\end{array}$ \\
\hline 5. & $\begin{array}{l}\text { Calon pengguna } \\
\text { (Mahasiswa, dosen } \\
\text { dan staff Universitas } \\
\text { Ma Chung) }\end{array}$ & $\begin{array}{l}\text { 1. } \begin{array}{l}\text { Dapat mengajukan permohonan peminjaman, } \\
\text { perbaikan maupun permohonan layanan IS/IT }\end{array} \\
\text { 2. Melihat jadwal peminjaman dan menerima no } \\
\text { antrian perbaikan maupun layanan } \\
\text { 3. Menerima notifikasi permohonan peminjaman, } \\
\text { permohonan layanan dan permohonan perbaikan } \\
\text { di setujui ataupun ditolak. } \\
\text { 4. Menerima notifikasi permohonan peminjaman, } \\
\text { permohonan layanan dan permohonan perbaikan } \\
\text { sudah selesai dikerjakan. }\end{array}$ & $\begin{array}{lr}\text { Data } & \text { transaksi } \\
\text { permohonan } & \\
\text { peminjaman } & \text { fasilitas } \\
\text { IT, permohonan } \\
\text { perbaikan } r \\
\text { permohonan } & \text { layanan } \\
\text { IS/IT } & \\
\text { Semua data } & \text { transaksi } \\
\text { layanan IS/IT } & \end{array}$ \\
\hline
\end{tabular}


URL : https://jurnal.machung.ac.id/index.php/kurawal

\begin{tabular}{|ll|}
\hline \multicolumn{2}{|c|}{ its_master_user } \\
\hline its kode user & varchar(10) $\leq \mathrm{pk}$ v \\
\hline its_username & varchar(20) \\
its_pasword & varchar(20) \\
its_hak_akses & integer \\
its_datecreated & date \\
\hline
\end{tabular}

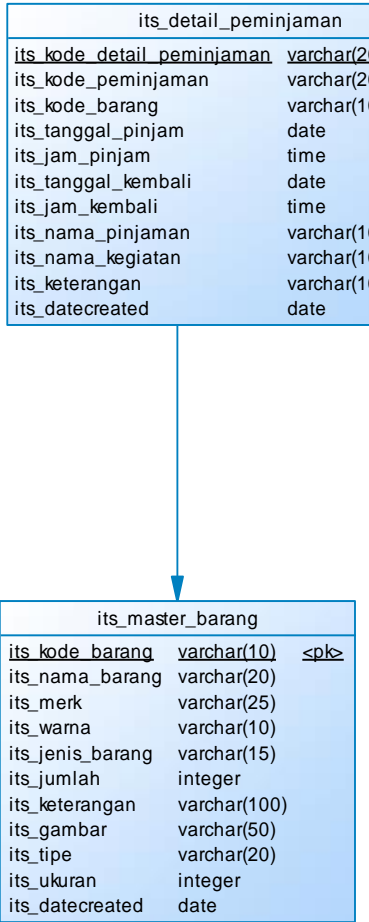

\begin{tabular}{|c|c|c|}
\hline \multicolumn{3}{|l|}{ its_rekapitulasi } \\
\hline its kode rekapitulasi & varchar(20) & $\leq \mathrm{pk}$, \\
\hline its_kode_peminjaman & $\operatorname{varchar}(20)$ & $\overline{\mathrm{kfk} 1\rangle}$ \\
\hline its_kode_permohonan_perbaikan & varchar(20) & $<f K 2>$ \\
\hline its_kode_layanan & $\operatorname{varchar}(20)$ & $<\mathrm{fk} 3\rangle$ \\
\hline its_total_peminjaman & integer & \\
\hline its_total_perbaikan & integer & \\
\hline its_total_layanan & integer & \\
\hline its_rating & integer & \\
\hline its_tanggal_rekap & date & \\
\hline
\end{tabular}

$\operatorname{varchar}(20) \leq 0$
$\frac{<p l o}{<0)}$
$<\mathrm{fk} 1>$
$<\mathrm{fk} 2>$

its kode

$\operatorname{archar}(100)$ $\operatorname{rrchar}(100)$

$<$

its_tang

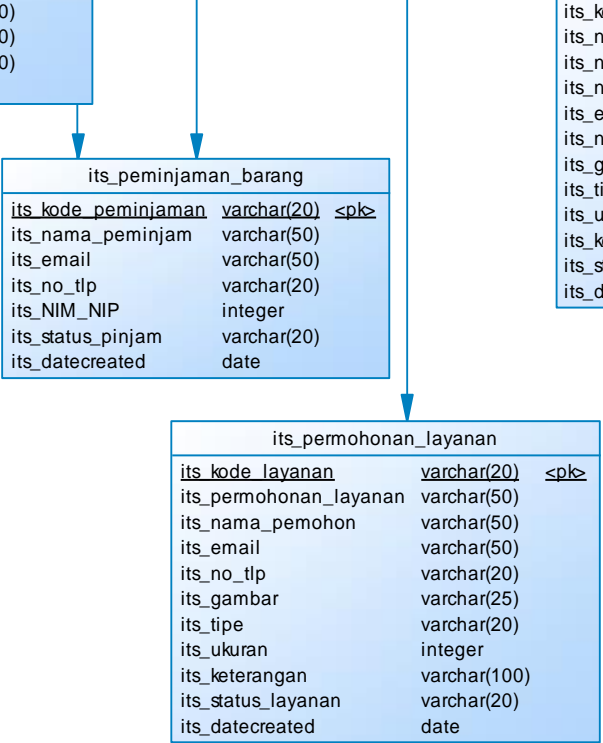
kode permohonan perbaikan varchar(20) $\leq p$ its_kode_ruangan $\operatorname{varchar}(20)<\mathrm{fk}>$ varchar(50) varchar(50)

its_email varchar $(50)$

s_gambar

s_tipe

varchar $(50)$ varchar(20)

sukuran varchar(25)

s_keterangan varchar(20)

varchar $(100)$ $\operatorname{varchar}(20)$

datecreated date

Gambar 5 Entity Relational Diagram (ERD)

FORM PERMOHONAN PEMINJAMAN FASILITAS IT
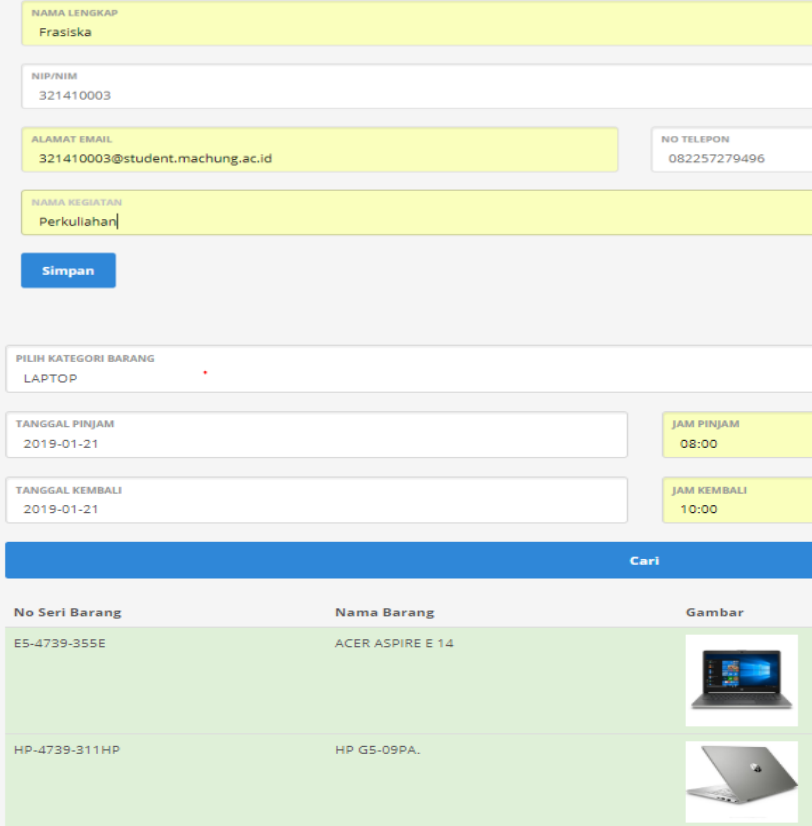

Gambar 6 Diagram aktivitas permohonan peminjaman dan penjadwalan 
URL : https://jurnal.machung.ac.id/index.php/kurawal

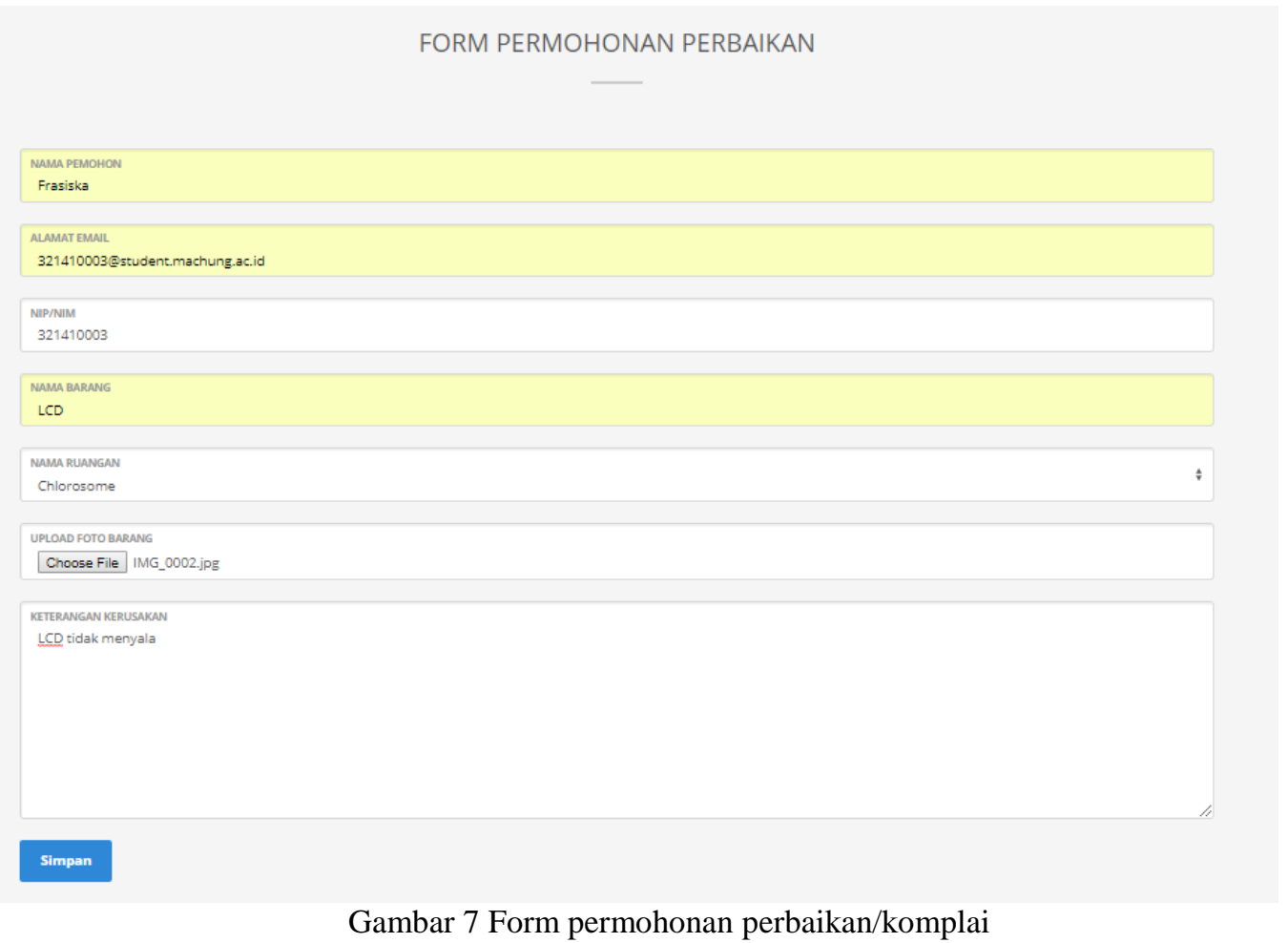

- Form permohonan layanan data (Gambar 8).

Sistem menampilkan form permohonan layanan data, kemudian pengguna menginputkan data diri yang disertai foto KTM atau KTP dan juga permohonan data yang diperlukan, seperti pengguna lupa password e-mail.

\section{HASIL DAN PEMBAHASAN}

Berdasarkan rancangan yang telah dibuat, maka dibangun sistem informasi layanan TI Universitas Ma Chung berbasis web dengan lima hak akses utama, yaitu kepala UPT Sistem Informasi, admin bagian permohonan peminjaman dan penjadwalan, admin bagian perbaikan, admin bagian layanan dan pengguna (dosen, staff dan mahasiswa). Tiap hak akses memiliki tampilan menu yang berbeda. Bagian ini hanya akan menampilkan hasil dari pengembangan. Laporan yang dihasilkan sesuai dengan perancangan yang telah dibuat sebelumnya, yaitu laporan peminjaman, laporan perbaikan, laporan layanan, dan laporan barang dengan peminjaman tertinggi.

\section{KESIMPULAN}

Sistem informasi layanan TI Universitas Ma Chung (IT Help-desk management system) ini dibangun dengan bahasa pemrograman PHP dan database MySQL dengan menerapkan metode pengembangan sistem Three Major Phase. Sistem dikembangkan menyesuaikan proses bisnis peminjaman dan penjadwalan pada UPT Sistem Informasi. Sistem ini dapat membantu UPT Sistem Informasi untuk:

- Membantu staff UPT Sistem Informasi untuk menginputkan data master.

- Membantu UPT Sistem Informasi transaksi peminjaman barang mulai dari peminjaman barang sampai pengembalian barang.

Sistem dapat melakukan proses blokir user jika terlambat melakukan pengembalian barang. 


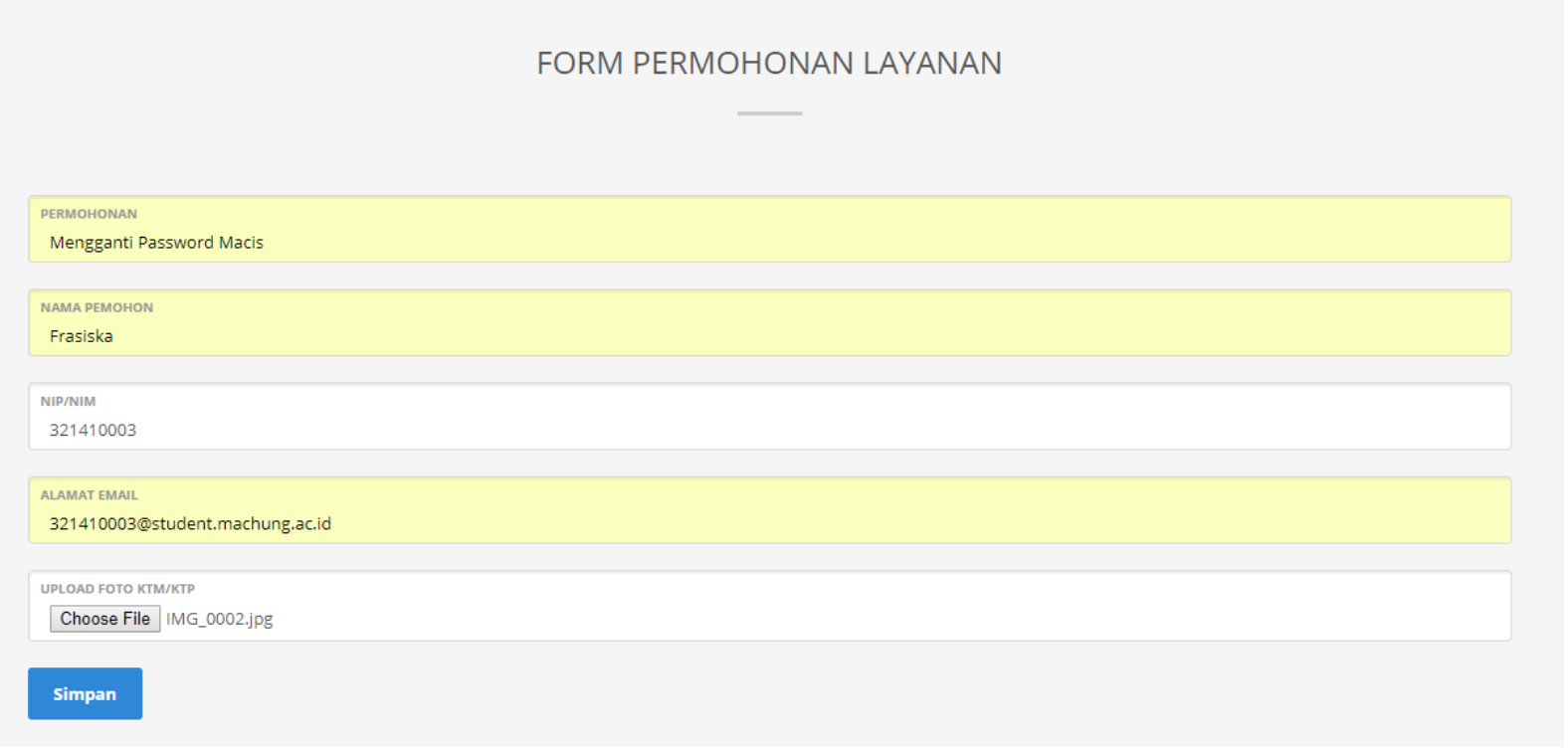

Gambar 8 Form permohonan layanan

- Membantu UPT Sistem Informasi dalam memberikan informasi kondisi barang.

- Mencatat transaksi perbaikan mulai dari permohonan perbaikan yang masuk hingga perbaikan yang telah selesai dilakukan.

- Sistem dapat membantu UPT Sistem Informasi dalam melakukan pengambilan keputusan terhadap barang yang sering mengalami kerusakan.

- Mencatat transaksi layanan mulai dari permohonan data yang masuk hingga layanan yang telah selesai dilakukan.

- UPT Sistem Informasi dapat melihat grafik keluar masuk barang, sehingga dapat dengan mudah memeriksa barang yang ada.

- Sistem dapat membantu UPT Sistem Informasi dalam melakukan pengecekan barang yang sering dipinjam dan mencatat setiap kerusakan barang.

- Sistem dapat membantu user mengetahui apakah barang yang akan dipinjam masih tersedia atau tidak.

- Sistem dapat membantu user dalam melakukan pengecekan apakah permohonan yang telah diajukan sudah disetujui oleh admin dengan memberikan notifikasi melalui email.

Saran pengembangan Sistem informasi layanan TI Universitas Ma Chung (IT Help-desk management system) adalah sebagai berikut:

1) Sistem dikembangkan dengan mengintegrasikan notifikasi dengan nomor HP agar dapat tersampaikan pada user melalui SMS, tanpa harus terhubung ke internet atau login web terlebih dahulu.

\section{REFERENSI}

[1] Queen Anugerah Aguslia, 2014, Sistem Informasi E-event (Studi kasus: Universitas Ma Chung).

[2] Irham Fuadika, 2015, Sistem Informasi Jasa Service Software/Hardware Pada Cv. Duta Teknologi Berbasis Desktop, [online] Available at: 
<http://elib.unikom.ac.id/files/disk1/674/jbptunikompp-gdl-irhamfuadi-33671-1unikom_i-l.pdf> [Accessed 3 Sept. 2018].

[3] Rico, 2016, Analisis dan Perancangan Sistem Informas IT-Helpdesk pada PT. Lontar Papyrus Pulp \& Paper Industry [online] Available at: <http://ejournal.stikomdb.ac.id/index.php/mediasisfo/article/download/234/221/ > [Accessed 3 Sept. 2018].

[4] EdrawSoft, 2018, UML Use Case Diagram Symbols, [online] Available at: $<$ https://www.edrawsoft.com/uml-usecase-symbols.php> [Accessed pada 3 Mar. 2018].

[5] Sugiarti, Y., 2013, Analisis dan Perancangan UML (Unified Modeling Language), Graha Ilmu, Yogyakarta.

[6] Winarno St, E., Zaki, A. and SmithDev, 2014, Pemrograman Web Berbasis Html 5,Php, \& Javascript, PT Elex Media Koputindo, Jakarta

[7] Visual Paradigm, 2018, What is Class Diagram? [online] Available at: $<$ https://www.visual-paradigm.com/guide/uml-unified-modeling-language/what-is-classdiagram/> [Accessed 18 May 2018].

[8] Kendall, J.E. and Kendall, K.E., 2013, Systems Analysis and Design, 9e ed, Pretince Hall, United States.

[9] Kadir, A., 2014, Pengenalan Sistem Informasi Edisi Revisi, Andi, Yogyakarta. 